\title{
Forces and Stresses Generated During Rigging Operations
}

\author{
Brian Kane, Sergio Brena, and Wesley Autio
}

\begin{abstract}
Rigging is one of the most dangerous aspects of arboriculture, yet there are no robust studies of the forces and stresses generated during rigging. Compounding the inherent danger of rigging is the structurally-deficient condition of many trees that are removed using rigging. Red pines (Pinus resinosa Ait.) $(n=13)$ were removed using conventional techniques, and forces at the block and in the rope were measured as the top, and four subsequent pieces were rigged with a block and Port-A-Wrap. Stress in the trunk at breast height was calculated from strain measurements and each tree's modulus of elasticity. Multiple regression was used to determine which independent variables (mass of piece, fall distance and fall ratio, notch angle and depth) best predicted forces. Tops and pieces exhibited different relationships with mass, which was the best predictor of force at the block and tension in the rope. Other variables were not as important and exhibited counter-intuitive relationships with forces. There were few differences in stress generated when removing tops and pieces, which appeared to be due to greater deflection higher in the trunk when tops were removed.

Key Words. Rigging; Trunk Stress; Biomechanics.
\end{abstract}

Rigging is one of the most dangerous aspects of arboriculture. Removing large branches and pieces of wood secured by ropes involves dynamic forces as pieces, either swing or fall some distance before the rope decelerates and stops them. The tree responds dynamically by oscillating because it is a flexible structure. Rigging generates large stresses on the rigging gear and on the tree itself. Increasing this inherent danger is the structurallydeficient condition of many trees that are removed using rigging. Rigging operations have resulted in climber fatalities (Ball and Vosberg 2004). Excluding injuries resulting from improper rigging, there are two basic risks to the climber and ground crew during rigging operations: failure of the rigging gear (ropes, pulleys, friction devices) and failure of the tree or part thereof.

Arborists use different types of rigging for different situations (Donzelli and Lilly 2001), but the greatest stresses are generated when the rigging point (i.e., where the lowering rope is anchored to the tree) is below the piece being removed. For this situation, the rigging point is a block attached to the tree by a sling, and the lowering rope passes through the block and is tied off to the piece being removed (Figure 1). Commonly referred to as, "butt-hitching" (Lilly 2001), this type of rigging is usually associated with tree removal, because once the branches have been removed, there are no more rigging points above the piece to be removed. Because the piece being removed free falls, its velocity is greater when the lowering rope decelerates and stops the piece. The increased velocity of the piece causes the stopping force exerted by the lowering rope on the piece to substantially exceed the weight of the piece. Although the stopping force can be reduced by gradually decelerating the piece (this is known as "letting a piece run"), in some cases, there is no room to employ this alternative. When the stopping force acts quickly (e.g., an abrupt deceleration), the force required to decelerate the piece is, theoretically, much greater than in the former case.

Advances in rigging gear and techniques may instill greater confidence in climbers to take bigger pieces of wood. Climbers relying on working load limits of rigging gear may not appreciate the potentially large forces involved in taking large pieces. Furthermore, while it is comparatively easy to test the breaking strength of ropes, slings, and blocks (either working load limits or breaking strengths are printed on such equipment), there are very few studies that have measured the breaking strength of large shade trees (Kane and Clouston 2008). Further complicating the issue is the difficulty in analyzing trees with engineering equations, because the simplifying assumptions upon which equations are derived are often violated.

In spite of the great risk to life and property, there are no robust studies that have investigated the forces and stresses involved in rigging operations. Detter (2008) reported results from a laboratory study in which high speed photography was used

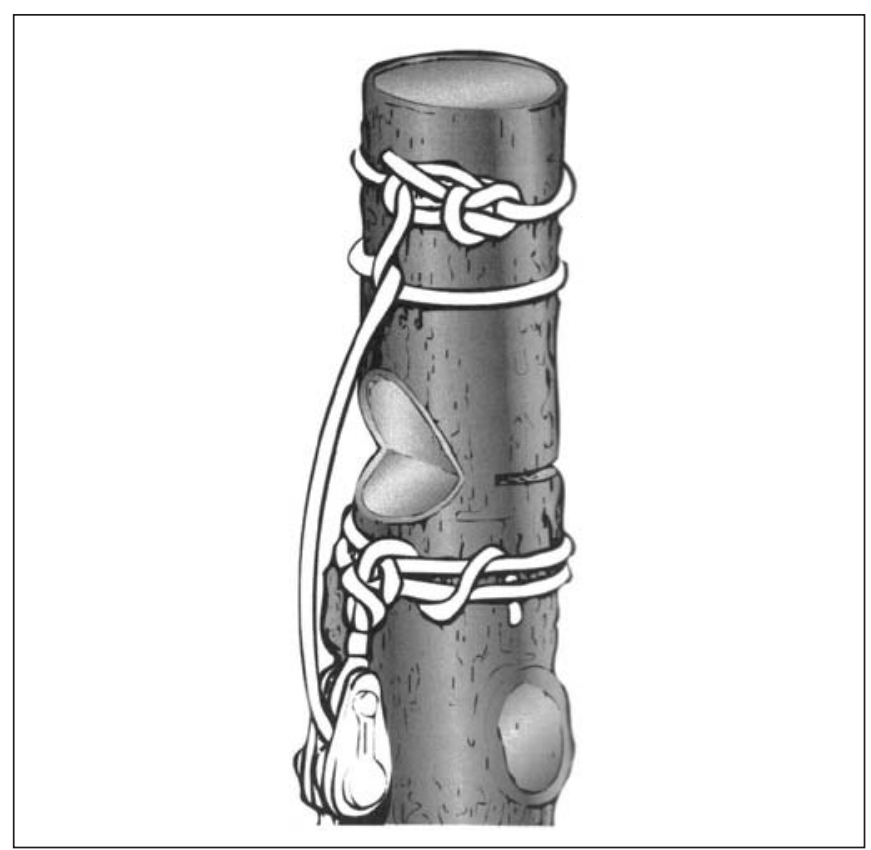

Figure 1. Diagram of how pieces were removed by "butt-hitching" [from Lilly (2001), used with permission]. 
to track trajectories of pieces removed with rigging, but only measured a few pieces and the single tree (actually a section of trunk removed from a tree) was not tested in situ. Blair (1989) discussed the advantages and disadvantages of various removal techniques, stating his preference for taking single large pieces to reduce the likelihood of accidents during cutting. While noble, this approach was not based on empirical data, nor did it address the issue of overloading the tree during rigging operations.

From theoretical considerations, the tension (t) in the rope during rigging operations can be calculated by (Pavier 1998):

$$
t=m g *\left[1+\sqrt{1+\frac{2 k F}{m g}}\right]
$$

where $\mathrm{m}$ is the mass of the falling object $(\mathrm{kg}), \mathrm{g}$ is the acceleration due to gravity $\left(\mathrm{m}^{*} \mathrm{~s}^{-2}\right), \mathrm{F}$ is the fall factor (dimensionless), the ratio between the distance the object falls and the length of rope in the system, and $\mathrm{k}$ is a measure of the rope's elasticity $(\mathrm{N})$ :

$$
\mathrm{k}=\mathrm{P} *(\mathrm{~L} / \mathrm{x})
$$

where $\mathrm{P}$ is the force that extends the rope $(\mathrm{N}), \mathrm{x}$ is the rope's extension $(\mathrm{m})$, and $\mathrm{L}$ is the initial length of rope $(\mathrm{m})$ (McLaren 2006). Equation 1 is derived from equating the loss of potential energy of a falling mass and the gain in strain energy of the rope as it extends. However, the equation is less applicable as the rope's elasticity decreases with time and so must be considered only an estimate. The tension in the rope must be doubled to estimate the force in the block and sling, which is transferred to the tree at the rigging point. The force at the block would be somewhat less than twice the tension in the rope because friction in the block would reduce the tension in the rope between the block and the friction device that anchors the rope at the base of the tree (Donzelli 1999). For a $227 \mathrm{~kg}(500 \mathrm{lb})$ mass, Donzelli (1999) determined that the reduction in rope tension between the block and the friction device ranged from $4 \%-30 \%$, depending on the type of block used.

The objectives of the present study were to determine the forces generated during rigging operations and to investigate how these forces affect rigging gear and tree stability. In particular, it was desired to determine 1) the best physical and arboricultural predictors of tension in the rope and force at block, and 2) how force at the block translated into stress in the trunk, including a trunk with decay. Answers to these questions were expected to inform the broader question of how massive a piece can be without risking failure of the rigging gear or the tree.

\section{METHODS AND MATERIALS}

Thirteen red pines (Pinus resinosa Ait.) growing in a plantation in Amherst, MA, USA were selected according to their physical similarity, proximity to an access road, lack of structural defects, and distance from other trees. The trees averaged $30.6 \mathrm{~cm}(1 \mathrm{ft})$ dbh [4.57 cm (1.8 in) standard deviation] and $21.6 \mathrm{~m}(70.87 \mathrm{ft})$ tall $[1.64 \mathrm{~m}(5.38 \mathrm{ft})$ standard deviation]. Each was rigged for removal in accordance with conventional arboricultural practice. In particular, lateral branches were removed until a top remained that was small enough to remove without risking failure of the rigging gear or tree. A block [ISC Ltd., Glasgow, Scotland, 2000 $\mathrm{kg}$ (440.92 lb) working load limit, $20 \mathrm{~mm}(0.79 \mathrm{in})$ maximum rope diameter] was attached with a $12.7 \mathrm{~mm}$ (0.5 in) Amsteel® (Samson Rope Technologies Inc., Ferndale, WA) sling approximately 7-10 $\mathrm{cm}$ (2.76-3.94 in) below where the cut would be made to remove the top from the trunk. A notch was made in the intended felling direction and the lowering rope $[12.7 \mathrm{~mm}(0.5$ in) diameter Stable Braid (Samson Rope Technologies Inc., Ferndale, WA)] was run through the block and tied off to the top with a marl and a running bowline. The felling cut was made opposite the notch and the top was pulled by hand, as necessary, with a tag line to ensure that it fell in the appropriate direction. The lowering rope was secured to the base of the tree by a steel Port-A-Wrap (Buckingham Mfg., Binghamton, NY), which was also attached to the tree by a $12.7 \mathrm{~mm}$ diameter Amsteel sling. Securing the rope in this fashion caused the top to stop abruptly, generating the intended large forces. Removal of tops and pieces was videotaped with a digital video camcorder (Canon GL2, Jamesburg, NJ).

After the top was removed, its length, mass, and center of gravity were determined. The trunk diameter at the base of the top was measured both parallel and normal to the direction of fall. Four additional pieces were removed from each tree, except for two trees, for which three and five additional pieces were removed, respectively. Not including the top, pieces were $1.83 \mathrm{~m}(6 \mathrm{ft})$ long, and were removed in the same fashion as the top. The mass, diameters (at the top and bottom of the piece), and center of gravity were also determined for each piece.

Forces at the block and Port-A-Wrap were measured with dynamometers [Dillon EDxtreme, $44 \mathrm{kN}(10,000 \mathrm{lbf})$ and $22 \mathrm{kN}(5,000$ lbf) capacity, respectively, accurate to $0.1 \%$ of capacity]. The peak load was recorded by each dynamometer, sampling at $60 \mathrm{~Hz}$.

The amount of rope in the rigging system and distance of fall were measured for the top and each piece so that the fall factor (see equation 1) could be calculated. Assuming minimal slack in the lowering rope, the distance of fall is twice the distance from the pin at the center of the sheave of the block to the center of gravity of the piece. Placement of a dynamometer between the sling and the block increased the fall distance compared to a work situation. The length of rope in the system is the distance from the Port-A-Wrap to the marl tied to the piece. The value for $\mathrm{k}$ for the lowering rope was determined using Equation 2, and the following values: $\mathrm{P}=4.6 \mathrm{kN}(1,034 \mathrm{lbf})$, which is $10 \%$ of the average tensile strength as provided by the manufacturer (Samson 2008), and $\mathrm{L} / \mathrm{x}=90.9$ [rope extension at $10 \%$ of average tensile strength is $1.1 \%$ (Samson 2008)]. The value of $\mathrm{k}$, however, must be considered an estimate because it is inherently difficult to calculate this property for ropes (McKenna et al. 2004).

At approximately $1 \mathrm{~m}(3.28 \mathrm{ft})$ above ground, strains in the trunk parallel and normal to the direction of fall of the piece were measured as described by James et al. (2006). To convert strain to stress, a normalized measure, it was necessary to calibrate trees before removing any pieces. Calibration involved pulling trees with a winch, which applied a bending moment to the tree, and recording the strain. Bending moment $(\mathrm{M})$ was converted to stress $(\sigma)$ by:

$$
\sigma=32 \mathrm{M} /\left(\pi \mathrm{ab}^{2}\right)
$$

where $\mathrm{a}$ and $\mathrm{b}$ are, respectively, the trunk diameters normal and parallel to the direction of the applied bending moment. As values of $a$ and $b$ in equation 3 diverge, stress calculations that assume a circular cross-section are increasingly erroneous (Kane 2007). As the tree was pulled with a winch, 
strains $(\varepsilon)$ in the trunk were measured normal and parallel to the applied load. The static elastic modulus (E) of the trunk was determined from stress and strain using Hooke's Law:

\section{[4] $\quad \mathrm{E}=\sigma / \varepsilon$.}

The value of $\mathrm{E}$ reflects the entire tree, including rotation of the root plate as the tree bends. This value was likely less than $\mathrm{E}$ values of the wood of the tree, but more consistent with a tree in situ. Strains measured during rigging operations, were converted into stresses using each tree's empiricallydetermined $\mathrm{E}$ value and a re-arranged version of equation 4:

$$
\sigma=\mathrm{E} \varepsilon
$$

Two stress values were collected for each top and piece, one measured parallel and one measured normal to the direction of fall. Measured strains reflect the dynamic modulus of elasticity, which, for timber is typically $5 \%-10 \%$ greater than the static elastic modulus (Bodig and Jayne 1993). Thus, the actual rigging-induced stress was likely 5\%-10\% greater than presented.

The percentage of the trunk cross-section that could be decayed was calculated by mathematically reducing the cross-section (i.e., reducing its second moment of area) until the maximum rigging-induced stress in the trunk equaled the strength of the tree. Strength of the tree was taken as $80 \%$ of the lower confidence interval of the average green wood strength of red pine from the Wood Handbook (Green et al. 1999). Previous studies have demonstrated that the strength of trees is approximately $80 \%$ of the strength of wood samples (Fons and Pong 1957; Kane and Clouston 2008).

Felling notches were assigned randomly with respect to width and depth. For tops, notches were classified as wide (i.e., $>60^{\circ}$ ) or narrow (i.e., $<30^{\circ}$ ); and as deep (i.e., notch depth $>$ $50 \%$ of diameter at the cut) or shallow (i.e., notch depth $<30 \%$ of diameter at the cut). In practice, notch depth and angle varied from the intended classification, so measured values were used in the analysis. For pieces, the classifications were the same, except that bypass cuts were also tested. Bypass cuts were considered to have an angle of $0^{\circ}$ and depth was not considered in the analysis. The theoretical principle behind testing notches was that notch width and depth would presumably affect the time it took the hinge to break. This, in turn, would affect both the time of free fall and how much of the potential energy of the piece was converted to strain energy in the trunk.

Using PROC REG of the SAS statistical analysis software (v. 9.1, SAS Institute, Cary, NC), two multiple linear regression models were built to determine which independent variables best predicted both force at the block and tension in the rope. The first model considered the following independent variables, chosen on the basis of their physical or practical importance: mass of piece, fall distance (which is twice the distance from the center of gravity of the piece to the sheave of the block), length of rope in the rigging, notch depth, and notch angle. A second model mimicked the first, but considered fall factor instead of its individual components. Preliminary investigation of scatter plots revealed 1) mass strongly influenced force, and 2) the forces generated by tops and pieces exhibited different relationships with mass. The latter observation was tested using dummy variables and simple linear regression to compare slopes and intercepts of the best-fit lines for forces generated by tops and pieces as predicted from mass. As a result of the preliminary analyses, both multiple linear regression models were repeated twice: first, tops and pieces were analyzed separately; second, force was divided by mass (the quotient is acceleration) and mass was not considered in the regressions. The MAXR option (SELECTION=MAXR) was used to add components to each model in a stepwise fashion.

Multiple linear regression was also used to investigate whether pertinent physical parameters such as mass, height of piece above ground, fall distance, length of rope, (fall factor was analyzed in a subsequent model as with the models to predict force), diameter at breast height, notch angle, or notch depth influenced stress, but tops and pieces were not analyzed separately. An analysis of variance (ANOVA) was used to determine whether force at the block (and force divided by mass), tension in the rope (and tension divided by mass), stress, strain, mass and length of pieces, and fall distance varied among pieces. Simple linear regression was used to investigate the relationship between 1) predicted force from equation 1 and measured force, and 2) force at the block and tension in the rope.

\section{RESULTS}

Force at the block and tension in the rope increased at a greater rate with increases in mass for pieces than for tops (Figure 2). Fall factor was not a significant predictor of force at the block, tension in the rope, or the normalized versions of those measures (i.e., after they were divided by the appropriate mass), so the remaining results refer only to the regression models that included distance of fall and rope length as separate variables. For all trees, the mean modulus of elasticity (standard deviation in parentheses) was 4,674 (1,440) MPa [678 (209) ksi] when measured in the direction of probe 1 and 4,569 (993) $\mathrm{MPa}[663(144) \mathrm{ksi}]$ for probe 2, a difference of $2.2 \%$.

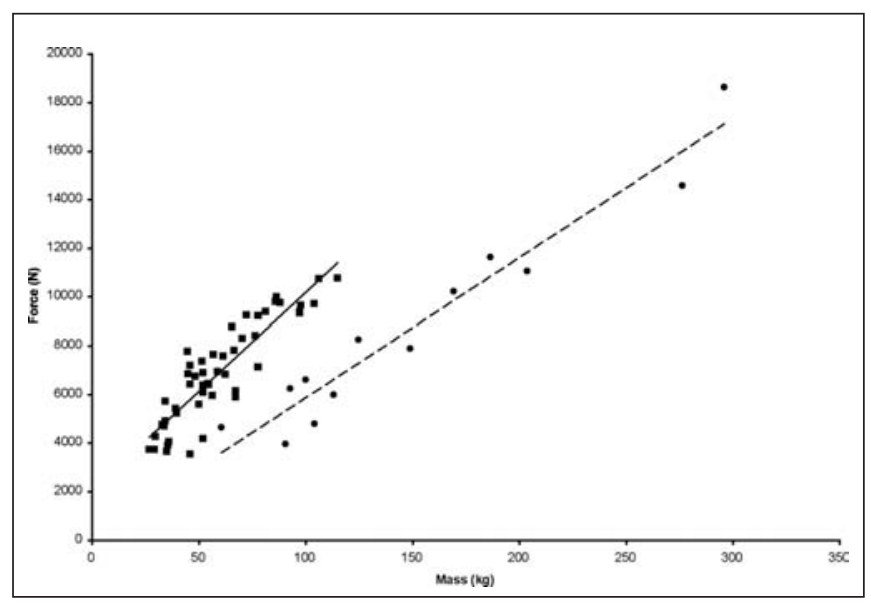

Figure 2. Prediction of force at the block by mass of the piece; the equation for pieces $(\square)$ was force $=89.2^{*}$ mass $+1644\left(r^{2}=0.80\right)$; the equation for tops $(\bullet)$ was force $=57.4^{\star}$ mass $+84\left(r^{2}=0.94\right)$. Although the intercepts for the two prediction equations were not significantly different, the slopes were $(P<0.0001)$. Slopes and intercepts for the prediction of rope tension from mass were also different between tops and pieces.

\section{Force at the Block}

For pieces, mass was the best and only significant predictor of force at the block, and the regression model was fairly robust 
(Table 1). The model was also consistent with physical parameters from equation 1 as the intercept was not significantly different from zero. For tops, mass was also the best predictor, and the model was more robust than for pieces. While fall distance was a significant predictor of force at the block for tops, it only accounted for $3.2 \%$ of the variance, compared with $94 \%$ for mass. It was also inversely proportional to force at the block, which was not consistent with equation 1 and the greater velocity of objects falling a greater distance in a gravitational field. The models to predict normalized force at the block (i.e., force divided by mass) were much less robust (adjusted $\mathrm{R}^{2}<0.25$ ) and nonsignificant $(P>0.20)$ for pieces and tops (data not presented).

Force at the block was greater for tops and piece 4 (the last piece removed), than for piece 1 (the piece just below the top), but did not differ among any other pieces (Table 2 ). In contrast, normalized force at the block was least for tops, and did not vary among the remaining pieces (Table 2).

\section{Tension in the Rope}

For tops and pieces, force at the block was slightly more than double the tension in the rope (Figure 3). For pieces, mass was the best predictor of tension in the rope (Table 1). Depth of the notch was a significant, but less important predictor, and, counter-intuitively, the relationship was inversely proportional (Table 1). The regression model was slightly less robust than the model predicting force at the block, and it conformed to the physical parameters from equation 1 since the intercept was not significantly different from zero (Table 1). For tops, mass was the best and only significant predictor of tension in the rope, and the model was more robust than for pieces (Table 1). There was weak evidence that fall distance was inversely proportional to tension in the rope (Table 1). Predictions of normalized tension in the rope were much less robust (adjusted $\left.\mathrm{R}^{2}<0.10\right)$ and not significant $(P>0.10)$ for pieces and tops. Tension in the rope followed the same pattern as force at the block: force at the block was greater for tops and piece 4 than for piece 1, but did not differ among any other pieces (Table 2). Normalized tension in the rope was least for tops, as well as greater for piece 2 than piece 3 (Table 2). For

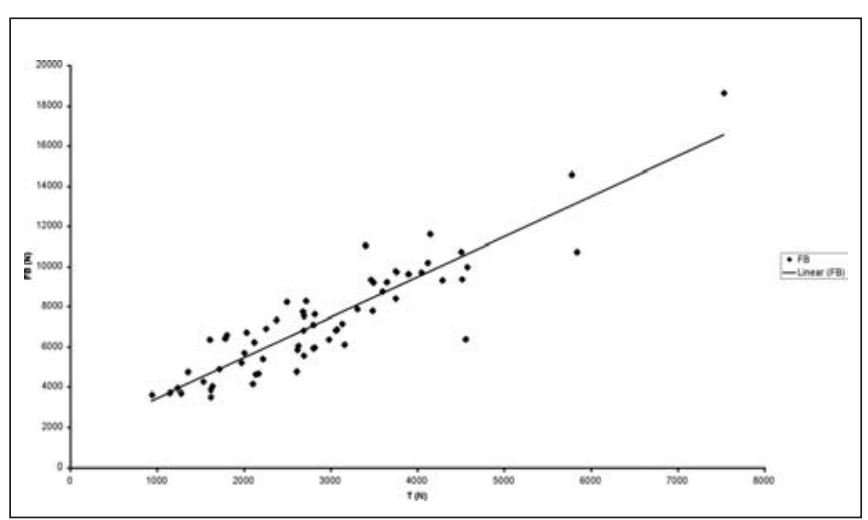

Figure 3. Prediction of force at the block (FB) by tension in the rope $(\mathrm{T})$. The linear prediction equation was $\mathrm{FB}=2.02^{\star} \mathrm{T}+1411$ $\left(r^{2}=0.80, P<0.0001\right)$, and it did not vary between tops and pieces, which have been plotted together.

Table 1. Results of multiple regression analyses to predict force at the block (FB) and tension in the rope (T) for Pieces and Tops. Estimate refers to either the intercept or the regression coefficient (slope) for each parameter in the model, SE is standard error of the estimate, and contribution to model is the percentage of the overall sum of squares contributed by the parameter.

\begin{tabular}{|c|c|c|c|c|c|c|c|c|c|c|c|c|}
\hline \multirow[b]{3}{*}{ Variable } & \multicolumn{6}{|c|}{ Pieces } & \multicolumn{6}{|c|}{$E P\left(P^{2}-096-P=00001\right)$} \\
\hline & \multicolumn{3}{|c|}{$\underline{\mathrm{FB}}\left(\mathrm{R}^{2}=0.78, P<0.0001\right)$} & \multicolumn{3}{|c|}{$\mathrm{T}\left(\mathrm{R}^{2}=0.71, P<0.0001\right)$} & \multicolumn{3}{|c|}{$\underline{\mathrm{FB}}\left(\mathrm{R}^{2}=0.96, P<0.0001\right)$} & \multicolumn{3}{|c|}{$\underline{\mathrm{T}}\left(\mathrm{R}^{2}=0.91, P=0.0003\right)$} \\
\hline & Estimate (SE) & $P$ & $\begin{array}{l}\text { Contribution } \\
\text { to model }\end{array}$ & Estimate (SE) & $P$ & $\begin{array}{l}\text { Contribution } \\
\text { to model }\end{array}$ & Estimate (SE) & $P$ & $\begin{array}{l}\text { Contribution } \\
\text { to model }\end{array}$ & Estimate (SE) & $P$ & $\begin{array}{l}\text { Contribution } \\
\text { to model }\end{array}$ \\
\hline Mass & $84.6(6.71)$ & 0.0001 & 77.6 & $36.8(3.81)$ & 0.0001 & 69.3 & $59.3(4.63)$ & 0.0001 & 94.0 & $24.0(2.73)$ & 0.0001 & 88.6 \\
\hline Fall distance & $-633(1,029)$ & 0.5420 & 0.2 & $758(585)$ & 0.2015 & 0.9 & $-557(199)$ & 0.0268 & 3.2 & $-251(117)$ & 0.0696 & 4.3 \\
\hline Cut angle & $5.53(5.92)$ & 0.3552 & 0.3 & $-1.24(3.36)$ & 0.7139 & 0.1 & $8.29(20.3)$ & 0.6949 & 0.1 & $-9.34(11.9)$ & 0.4592 & 0.5 \\
\hline Rope length & $-33.9(63.7)$ & 0.5969 & 0.1 & $6.36(36.2)$ & 0.8612 & 0.0 & $-82.6(261)$ & 0.7611 & 0.0 & $-32.3(154)$ & 0.8394 & 0.0 \\
\hline Cut depth & $-1,818(1,410)$ & 0.2038 & 2.1 & $-2,006(801)$ & 0.0160 & 3.3 & $-1,499(3,410)$ & 0.6734 & 0.1 & $-2,720(2,005)$ & 0.2171 & 1.1 \\
\hline
\end{tabular}

Table 2. Means (standard deviation in parentheses) for variables of interest: force at the block (FB), tension in the rope (T), force at the block / mass of the piece or top (AccelFB), tension in the rope / mass of the piece or top (AccelT), mass, fall distance, fall factor, and stress. Read down a column, means followed by the same letter are not different $(P>0.05)$ by Tukey's studentized range test.

\begin{tabular}{|c|c|c|c|c|c|c|c|c|c|c|c|}
\hline Piece & $n$ & $\mathrm{FB}(\mathrm{N})$ & $\mathrm{T}(\mathrm{N})$ & $\begin{array}{l}\text { AccelFB } \\
\left(\mathrm{m} / \mathrm{s}^{2}\right)\end{array}$ & $\begin{array}{l}\text { AccelT } \\
\left(\mathrm{m} / \mathrm{s}^{2}\right)\end{array}$ & $\begin{array}{l}\text { Mass } \\
(\mathrm{kg})\end{array}$ & $\begin{array}{l}\text { Fall } \\
\text { Distance } \\
(\mathrm{m})\end{array}$ & $\begin{array}{l}\text { Fall } \\
\text { Ratio }\end{array}$ & $\begin{array}{l}\text { Length } \\
\text { of Piece } \\
(\mathrm{m})\end{array}$ & $\begin{array}{l}\text { Stress }^{2} \\
(\mathrm{kPa})\end{array}$ & $\begin{array}{l}\text { Strain } \\
(\mathrm{mm} / \mathrm{mm})\end{array}$ \\
\hline & & 8,783 & 3,347 & 58.5 & 22.4 & 152 & 7.40 & 0.56 & 6.27 & 9,202 & 0.0021 \\
\hline \multirow[t]{2}{*}{ Top } & 13 & $(4,303) \mathrm{a}$ & $(1,734) \mathrm{a}$ & $(9.22) \mathrm{a}$ & (5.19) a & (72.7) a & $(1.38) \mathrm{a}$ & $(0.10) \mathrm{a}$ & $(1.00) \mathrm{a}$ & $(6,433) \mathrm{a}$ & $(0.0012) \mathrm{a}$ \\
\hline & & $5,439 \mathrm{~b}$ & 2,152 & 123 & 48.2 & 45.5 & 3.47 & 0.30 & 1.83 & 4,175 & 0.0009 \\
\hline \multirow[t]{2}{*}{1} & 13 & $(1,960) \mathrm{b}$ & $(819) \mathrm{b}$ & $(24.0) \mathrm{b}$ & $(8.80)$ bc & $(18.0) \mathrm{b}$ & $(0.14) \mathrm{b}$ & $(0.03) \mathrm{b}$ & $(0.00) \mathrm{b}$ & $(2,521) \mathrm{b}$ & $(0.0005) \mathrm{b}$ \\
\hline & & 7,057 & 2,991 & 126 & 52.9 & 58.2 & 3.47 & 0.36 & 1.83 & 5,388 & 0.0011 \\
\hline \multirow[t]{2}{*}{2} & 13 & $(1,864) a b c$ & $(1,110) a b c$ & $(22.5) \mathrm{b}$ & $(17.6) \mathrm{b}$ & $(21.0) \mathrm{b}$ & $(0.16) \mathrm{b}$ & $(0.05) \mathrm{b}$ & $(0.00) \mathrm{b}$ & $(3,514) b$ & $(0.0004) \mathrm{b}$ \\
\hline & & 7,235 & 2,835 & 113 & 43.2 & 65.6 & 3.48 & 0.45 & 1.83 & 6,437 & 0.0014 \\
\hline \multirow[t]{2}{*}{3} & 13 & $(2,015) \mathrm{abc}$ & $(1,014) \mathrm{abc}$ & $(15.2) \mathrm{b}$ & $(8.64) \mathrm{c}$ & $(22.0) \mathrm{b}$ & $(0.16) \mathrm{b}$ & $(0.07) \mathrm{c}$ & $(0.00) \mathrm{b}$ & $(4,010) a b$ & $(0.0006) \mathrm{b}$ \\
\hline & & 8,592 & 3,401 & 115 & 47.1 & 77.1 & 3.46 & 0.58 & 1.83 & 6,533 & 0.0014 \\
\hline 4 & 12 & $(2,526) \mathrm{ac}$ & $(1,038) \mathrm{ac}$ & $(22.4) \mathrm{b}$ & $(7.40) \mathrm{c}$ & $(25.3) \mathrm{b}$ & $(0.15) \mathrm{b}$ & $(0.10) \mathrm{a}$ & $(0.00) \mathrm{b}$ & $(4,231) a b$ & $(0.0006) \mathrm{b}$ \\
\hline
\end{tabular}

${ }^{2}$ Because stress was measured both normal and parallel to the direction of fall, the sample size was 25 ( 23 for piece 4 since one tree only had 3 pieces after the top). 


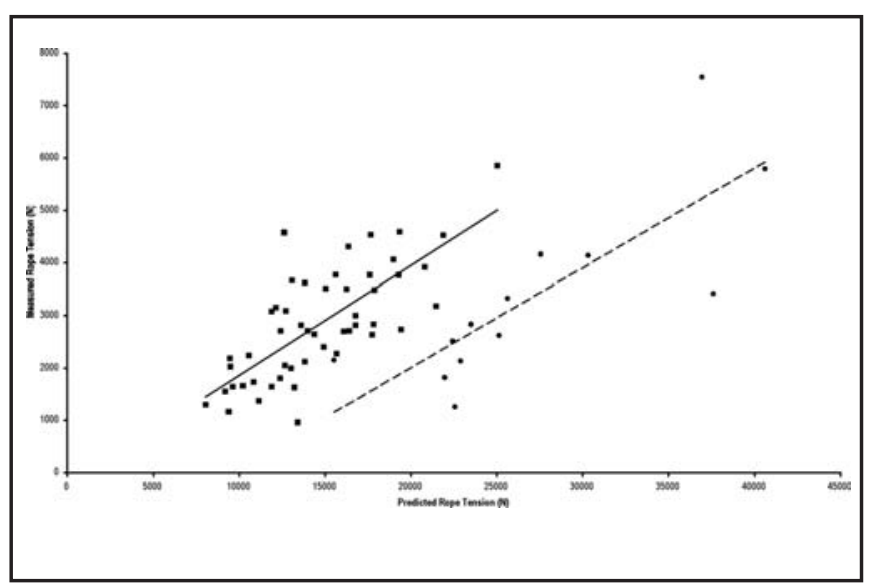

Figure 4. Measured $\left(T_{M}\right)$ vs. predicted $\left(T_{p}\right)$ tension in the rope for tops and pieces. The equation for tops $(\bullet)$ was $T_{M}=0.19 * T_{p}-1821$ $\left(r^{2}=0.64\right)$; the equation for pieces $(\square)$ was $T_{M}=0.21^{\star} T_{P}-264\left(r^{2}=\right.$ 0.55). Tension in the rope was predicted from Equation 1 in the text.

tops and pieces, tension in the rope was only $12 \%$ and $19 \%$, respectively, of predicted tension from equation 1 (Figure 4).

\section{Physical Parameters and Stress}

Tops were more massive and fell a greater distance before being stopped by the lowering rope than other pieces (Table 2). Fall factor, however, was greatest for tops and the last piece taken from each tree (piece 4) (Table 2). Tops were also longer than all pieces (Table 2). Trunk stress was greater for tops than the first two pieces removed after the top, but there were no other differences in stress among pieces (Table 2). None of the independent variables was a significant predictor of stress (data not presented), and the overall model was rather weak (adjusted $\mathrm{R}^{2}=0.12, P=0.0350$ ).

\section{DISCUSSION}

The law of conservation of energy stipulates that energy is neither created nor destroyed, but rather, changed from one form to another. In the case of a piece of wood removed from a tree, it has potential energy by virtue of its height. When it falls, the potential energy is converted to kinetic energy, which then does work in one of three ways: elongating the rope (axial strain energy in the rope), deflecting the trunk (bending strain energy in the tree), and displacing air. Of the three, rope elongation appears to be less significant, in light of the multiple regression models. Neither of the other types of work was quantified rigorously, but drag on pieces as they fell was arguably negligible. For tops, which still had foliated branches, the effect would have been greater, as others have observed (Mayhead et al. 1975, Detter 2008). Video images of the trunks clearly illustrate their violent oscillations, so it does not seem unreasonable to expect that pieces did considerable work to deflect trunks.

This observation, however, was not fully supported by the data, as stress generated by tops and all but the smallest pieces was similar. This disparity was an artifact of experimental procedure, as stress was measured on the trunks $1 \mathrm{~m}$ above ground. Beam mechanics predicts that the deflection of a tapered, cantilevered beam is proportional to the cube of its length (Soltis 1999), so the longer trunk would deflect more when loaded at the rigging point. Large deflections higher up the trunk, however, dissipate energy, which accounts for smaller strains measured $1 \mathrm{~m}$ above ground. Future investigations should attempt to measure deflection near the rigging point.

It was not surprising that mass was by far the best predictor of force at the block and tension in the rope for both tops and pieces, since it influences potential energy. It was initially surprising, however, that predictions of force at the block and tension in the rope were different for tops and pieces. Since trunks were longest and most slender when tops were removed, elementary beam mechanics predicts that trunk deflection will be greatest for tops because deflection is proportional to the cube of the length and inversely proportional to the fourth power of diameter of a beam (Lardner and Archer 1994). Video observations also support this idea, which reflects a greater proportion of potential energy of tops doing work to deflect the trunk. Thus, a smaller proportion of potential energy can do work to elongate the lowering rope. The findings that tops had similar values for force at the block and tension in the rope to other pieces (except for piece 1) but the smallest normalized values for force at the block and tension in the rope also supports this reasoning. Drag on the top as it fell may also have slowed its descent, and while this effect was not quantified, Detter (2008) observed reduced velocity of removed pieces when they still had branches attached.

Other variables expected to influence force at the block and tension in the rope (e.g., notch depth and angle, distance of fall, and length of rope in the system) were less influential. Fall factor did not predict force at the block or tension in the rope because equation 1 is most appropriate when the rope is elastic. Ropes used in rock climbing [for which equation 1 was originally derived (Pavier 1998)] are designed to stretch in order to reduce tension in the rope as it decelerates and stops a falling climber. Typical elongation in a rock climbing rope is $20 \%-30 \%$ during a fall, whereas the elongation of Stable Braid is only $1.1 \%$ at $10 \%$ of tensile strength (Samson 2008). Elongation tends to be bi-modal, with greater elongation when the rope is new and less elongation after the rope has been broken in (McLaren 2006). Since the rope used in the present study was not new, it is doubtful that elongation exceeded $1.1 \%$. However, some elongation would occur due to tightening of knots and slippage of the slings that held the block and port-a-wrap in place on the trunk. Indeed, for two tops, the force at the block was great enough to strip bark from the trunk as the sling and block slid about $0.5 \mathrm{~m}$ down the trunk. Incidentally, the latter may have also been a source of energy loss (due to friction).

Distance of fall did not predict force at the block and tension in the rope for pieces because all pieces were the same length, an artifact of experimental design. Since tops and pieces behaved differently, it was not prudent to perform a multiple regression with tops and pieces together, because it was not possible to separate the other effects from fall distance. For tops, however, the paradoxical finding that distance of fall was inversely proportional to force at the block and tension in the rope may also be attributed to greater trunk deflection as the top released from the trunk, but careful measurements of trunk deflection will have to be made before this attribution can be confirmed.

Depth and angle of the notch were also expected to influence force at the block and tension in the rope because shallower and deeper notches presumably cause the cut piece to release sooner from the trunk, which means they would have greater velocity (and thus would require greater stopping force). The data do not generally support this intuition, and while depth of the notch was 
a significant predictor of tension in the rope for pieces (and marginally significant for tops), the relationship was, paradoxically, inversely proportional. Intuitively, one expects that a deeper notch would cause the piece to release from the trunk sooner, which would increase the time it fell, and thus its velocity, before the rope stops it. It is unclear why this occurred, but careful investigation of the extent to which the depth and angle of the notch influence the length of time before the piece releases from the trunk should lend insight into this phenomenon. Detter (2008) observed possible differences in rotation of the cut piece depending on the type of notch (conventional or Humboldt), but there were too few observations and no statistical analyses to draw meaningful conclusions.

Notch depth and angle, as well as fall distance, are theoretically less important than mass, since velocity is proportional to the square root of the fall distance, while acceleration required to stop the piece is directly proportional to mass. The poor prediction of normalized force at the block and tension in the rope by any of the variables in those models supports the idea that mass was far more influential than either fall distance or depth and angle of the notch. Assuming that the intuitive expectation that the depth and angle of the notch influence the force required to stop a falling piece, it is unclear that their influence would supersede the influence of fall distance, because taking a longer piece increases fall distance linearly. Practically speaking, climbers are advised to 1) take a less massive piece, 2) take a shorter piece, 3) keep the block close to the cut, and 4) avoid slack in the lowering rope, since these factors will have a greater impact on stopping force than notch depth and angle. In many situations, however, any one of these recommendations may not apply or, worse, may cause a greater risk to the climber. For example, situations often arise in rigging when the climber intentionally adds slack to the rigging to avoid a cut piece from swinging back into the climber. Thus, the recommendations should not supersede a climber's good judgment when deciding on how to set the rigging, but rather help guide a climber's decisions with respect to safety. It is also important to exercise caution when extrapolating from the results of our small sample of trees. Species, tree structure, and alternate rigging practices may all affect our findings.

Some of the results agreed nicely with theoretical predictions, as shown by intercepts statistically similar to zero in the multiple regression models. Also expected from theory was the finding that force at the block was more than double tension in the rope. Since rope tension was measured in such a way that friction of the block was not accounted for, doubling rope tension would underestimate force at the block. The effect of friction added $20 \%$ to twice the tension in the rope to predict force at the block, within the range reported by Donzelli (1999), but more than the value assumed by Detter (2008). The finding that tension in the rope was only $17 \%$ of predicted tension from equation 1 was likely due to the impact effects of loading. Because the lowering rope was relatively inelastic, the impact force would not have been attenuated as much as by a rope that would have stretched more, thereby reducing the impact force, as predicted from equation 1 . Other factors that may have been relevant include inherent imprecision in assigning a value for $\mathrm{k}$ (McKenna et al. 2004) for Stable Braid, and the inapplicability of fall distance from equation 1. Pieces and tops did not free fall the entire fall distance, but rather, rotated on the hinge after the back cut was made. We did not quantify the rotation, but Detter's (2008) observations indicate that the angle of rotation is similar to the angle of the felling notch, which, in the present study, did not exceed $75^{\circ}$. Measured fall distance, then, would not have been more than twice the actual fall distance. Halving the fall distance used in equation 1 , however, only improved prediction to $26 \%$ for pieces and $17 \%$ for tops, so this explanation is insufficient. When we re-analyzed the data including only pieces removed with bypass cuts, which would be expected to cause pieces to free fall for the distance closest to the measured fall distance, the prediction of rope tension was similar to pieces removed with notches (19\%). Since equation 1 does not adequately describe rigging-induced forces, a new model that accounts for 1) the rotation (as opposed to free fall) of pieces (and how this affects fall distance), and 2) the comparative inelastic nature of lowering ropes is necessary.

Blair (1995) suggested that tension (t) in the rope could be estimated from the mass (m) of the piece using:

$$
t=m * d+m
$$

where $\mathrm{d}$ is the distance of fall. This guideline overestimated rope tension by $82 \%$ for tops but only $18 \%$ for pieces, which underscored the previously-described difference between tops and pieces with respect to the forces generated.

A final practical application of the findings was to estimate the allowable amount of decay in the trunk before risking tree failure during rigging. For concentric decay columns, tree failure would have occurred when the cross-section was $60 \%$ hollow; for decay columns offset to the periphery of the cross-section, tree failure would have occurred when the cross-section was only $45 \%$ hollow. These values must be taken with extreme caution, since stress was only measured at the base of the tree and the values presented are likely smaller than actual stress since we used the static elastic modulus in equations 4 and 5 . The impact of the piece being removed on the trunk below the rigging point might cause failure at a different location than where stress was measured. A climber's experience may still be more valuable in determining whether a tree is safe to climb, but the hollow cross-sections estimated above can provide some guidance in assessing the safety of rigging a particular tree.

\section{CONCLUSION}

We have demonstrated the importance of mass in predicting rigging-induced forces, as well as interesting differences between tops and pieces with respect to force and stress. We have also shown that predicting force from the theoretical analysis derived for falling rock climbers is less applicable in rigging trees. Such disparities highlight the need for additional studies to assess the forces and stresses generated during rigging. Future areas of investigation include exploring differences between tops and pieces, measuring deflection at the rigging point, comparing pieces of similar mass while varying fall distance, and more precisely measuring the effect of notches and hinges on movement of the piece after cutting. Finally, a more robust analysis with respect to the dynamic response of trees during rigging would be most helpful.

Acknowledgments. The authors gratefully acknowledge the assistance of Ed Carpenter, Melissa Duffy, Mollie Freilicher, Marcy Gladdys, Dan Goodman, and Noel Watkins, as well as two anonymous reviewers for helpful comments on earlier versions of the manuscript. 


\section{LITERATURE CITED}

Ball, J. and S. Vosberg. 2004. Tree worker safety: which accidents occur in our industry. Arborist News 13:25-27.

Blair, D.F. 1989. Rigging for removal. Journal of Arboriculture 15:84-88.

Blair, D.F. 1995. Arborist Equipment: A Guide to the Tools and Equipment of Tree Maintenance and Removal. International Society of Arboriculture, Champaign, IL. 291 pp.

Bodig, J. and B.A. Jayne. 1993. Mechanics of Wood and Wood Composites. Krieger Publishing Co., Malabar, FL 712 pp.

Detter, A. 2008. Evaluation of current rigging techniques used to dismantle trees. Arborist News 17:34-37.

Donzelli, P.S. 1999. Comparison of the frictional properties of several popular arborist blocks. Journal of Arboriculture 25:61-68.

Donzelli, P.S. and S. Lilly. 2001. The Art and Science of Practical Rigging. International Society of Arboriculture, Champaign, IL. 172 pp.

Fons, W.L. and W.Y. Pong. 1957. Tree breakage characteristics under static loading; ponderosa pine. USDA Forest Service, Div. Forest Fire Research, Interim Tech. Rep. AFSWP-867. 51 pp.

Green, D.W., J.E. Winandy, and D.E. Kretschmann. 1999. Mechanical properties of wood. In Wood Handbook-wood as an engineering material. Gen. Tech. Rep. FPL-GTR-113. Madison, WI, USDA Forest Service Forest Products Laboratory 463 pp.

James, K.R., N. Haritos, and P.K. Ades. 2006. Mechanical stability of trees under dynamic loads. Am. J. Bot. 93: 1361-1369.

Kane, B. "Branch Strength of Bradford Pear (Pyrus calleryana var. 'Bradford')." 2007. Arboriculture \& Urban Forestry 33:283-291.

Kane, B. and P. Clouston. 2008. Tree pulling of large shade trees in the genus Acer. Arboriculture \& Urban Forestry 34:101-109.

Lardner, T.J. and R.R. Archer. 1994. Mechanics of Solids. McGraw Hill NY, NY. 802 pp.

Lilly, S. 2001. Arborists' Certification Study Guide. International Society of Arboriculture, Champaign, IL. 222 pp.

McLaren, A.J. 2006. Design and performance of ropes for climbing and sailing. Proceedings of the Institute of Mechanical Engineers Part L: Journal of Materials: Design and Applications 220:1-12.

McKenna, H.A., J.W.S. Hearle, and N. O'Hear. 2004. Handbook of Fibre Rope Technology. Woodhead Publishing Ltd., Cambridge, England. 416 pp.

Pavier, M. 1998. Experimental and theoretical simulations of climbing falls. Sports Engineering 1:79-91.

Samson. 2008. Samson Professional Arborist Ropes. <http://samsonrope. com/site_files/Arborist_Catalog.pdf>

Soltis, L.A. 1999. Structural Analysis Equations. In Wood Handbookwood as an engineering material. Gen. Tech. Rep. FPL-GTR-113. Madison, WI, USDA Forest Service Forest Products Laboratory 463 pp.

Brian Kane (corresponding author)

University of Massachusetts - NRC

126 Holdsworth Hall

Amherst, Massachusetts 01003, US

\section{Sergio Brena}

University of Massachusetts

Civil and Environmental Engineering

Amherst, Massachusetts 01003, US
Wesley Autio

University of Massachusetts

Plant, Soil, and Insect Science

Amherst, Massachusetts 01003, US

Résumé. Le gréement est l'un des aspects les plus dangereux en arboriculture, quoiqu'il n'y a pas d'études robustes sur les forces et les stress générés durant le gréage. Une composante du danger inhérent au gréement est la condition structuralement déficiente de plusieurs arbres qui sont abattus au moyen d'un gréement. Des pins rouges (Pinus resinosa) $(n=13)$ ont été abattus au moyen de techniques conventionnelles et les forces au niveau du bloc et de la corde ont été mesurées au niveau du sommet ainsi que de quatre pièces (ou sections) subséquentes ont été gréées et descendues à l'aide d'un système approprié. Le stress sur le tronc au niveau du D.H.P. a été calculé au moyen de mesures de tension ainsi que le module d'élasticité de chacun des arbres. Une régression multiple a été employée pour déterminer quelles variables indépendantes (masse de la pièce, hauteur de chute et ratio de hauteur, angle et profondeur de l'encoche d'abattage) prédisait le mieux les forces. Les sommets et les pièces présentaient différentes relations avec la masse qui était la meilleure variable de prédiction de la force au niveau du bloc et de la tension sur la corde. Les autres variables n'étaient pas aussi importantes et présentaient des relations mesurables plus intuitives avec la force. Il y avait peu de différences dans le stress généré lorsque les sommets et les pièces étaient coupées, ce qui semblait être dû à une plus grande déflection de la partie supérieure du tronc lorsque les sommets étaient coupés.

Zusammenfassung. Rigging (Abseilen) ist eine der gefährlichsten Arbeiten in der Baumpflege, dennoch gibt es bislang kaum brauchbare Studien über die während des Abseilens auftretenden Kräfte und Spannungsfaktoren. Bei vielen Bäumen, die durch Abseilen gefällt werden, ist die Verbindung enthaltener Gefahren oft strukturell mangelhaft. Rotkiefern (Pinus resinosa Ait.) $(n=13)$ wurden mit konventionellen Methoden entfernt, dabei wurden die höchsten Kräfte am Block und am Seil gemessen und der Baum in vier Abschnitten abgeseilt. Die auftretenden Spannungen im Stamm in Brusthöhe wurden anhand der entsprechenden Baumelastizität kalkuliert. Die multiple Regression wurde verwendet, um zu bestimmen, welche unabhängigen Variablen (Holzmasse, Fallhöhe und -rate, Fällkerbwinkel und -tiefe) die besten Vorhersagen über auftretende Kräfte zulassen. Baumspitzen und -teile zeigten unterschiedliche Relationen bezüglich ihrer Massen, welche die besten Aussagen über auftretende Kräfte und Spannungen im Seil zuließen. Es gab ein paar Unterschiede bei den erzeugten Spannungen, wenn Spitzen oder Teile gefällt wurden. Die Ursache dafür schien in größerer Aufschwingung in oberen Teilen des Stammes, wenn die Spitze entfernt wird.

Resumen. El cordaje es uno de los más peligrosos aspectos de la arboricultura, aunque no hay estudios robustos de las fuerzas y tensión generados durante el aparejo. La composición del peligro inherente del cordaje está en la condición estructuralmente deficiente de muchos árboles que son removidos usando aparejos. Trece pinos rojos (Pinus resinosa Ait.) fueron derribados usando técnicas convencionales, cuatro piezas fueron removidas con una polea y un ancla y se midieron las fuerzas en la polea y en la cuerda. Se calculó la tensión en el tronco, a la altura del pecho, de mediciones de resistencia y módulos de elasticidad de los árboles. Se usó regresión múltiple para determinar cual variable independiente (masa de la pieza, distancia de la caída y relación de caída, ángulo y profundidad del corte) predijeron mejor las fuerzas generadas. Las puntas y las piezas exhibieron diferentes relaciones con la masa, las cuales fueron las mejores para predecir la fuerza en la polea y la tensión en la cuerda. Otras variables no fueron tan importantes y no exhibieron relaciones con las fuerzas. Hubo pocas diferencias en el estrés generado cuando se removieron las puntas y piezas, lo cual parece deberse a la mayor deflexión en el tronco cuando las puntas son removidas. 